\title{
FABRICATION AND SIMULATION OF FEEDSTOCK FOR TITANIUM-POWDER INJECTION-MOLDING CORTICAL-BONE SCREWS
}

\author{
IZDELAVA IN SIMULACIJA VHODNE SUROVINE ZA \\ INJEKCIJSKO BRIZGANJE VIJAKA NA OSNOVI TITANOVEGA \\ PRAHU ZA KORTIKALNO KOST
}

\author{
Levent Urtekin ${ }^{1}$, Asım Genç ${ }^{2}$, Fatih Bozkurt ${ }^{3}$ \\ ${ }^{1}$ Ahi Evran University, Engineering Faculty, Mechanical Engineering Department, 40100 Kırsehir, Turkey \\ ${ }^{2}$ Gazi University TUSAS-Kazan Vocational School, 06500 Ankara, Turkey \\ ${ }^{3}$ Vocational School of Transportation, Eskisehir Technical university, 26470 Eskisehir, Turkey \\ Prejem rokopisa - received: 2018-04-26; sprejem za objavo - accepted for publication: 2018-11-29
}

\author{
doi: $10.17222 / \mathrm{mit} .2018 .088$
}

Titanium-powder injection molding is a combination of plastic injection and powder metallurgy. Using this technology, near-net titanium parts are produced. In this study, feedstock-development experiments were performed with Ti-6Al-4V powders and binders for the production of titanium cortical-bone screws. Critical solid-loading and optimum solid-loading values were determined to specify the most appropriate binder system and ratio by volume. The critical solid-loading rate was determined as $62 \%$ by volume while the optimum solid-loading rate was $60 \%$ by volume. The rheological properties of the feedstocks were obtained with a capillary rheometer, and the thermal properties with a TGA analysis. The rheological behavior and thermal properties of PW/PE/SA and PEG8000/PP/SA feedstocks at different mixing ratios were determined. A simulation of the flow was made with the Moldflow program, designing a screw and a mold. For the two different feedstocks, skeletal binders PP and $\mathrm{PE}$ were identified and simulations were carried out. The knowledge that the feedstock skeletal-binder properties predominate was obtained as the data for the flow in the mold in the light. Experiments and simulations showed that the water-based feedstock is a suitable binder system for the cortical-bone screw molding.

Keywords: feedstock, rheology, powder injection molding, Ti-6Al-4V cortical-bone screw

Injekcijsko brizganje prahov na osnovi titana (Ti) je kombinacija brizganja plastike in metalurgije prahov (PM). S to tehnologijo je možno izdelati kovinske izdelke kompliciranih oblik. V študiji so avtorji na osnovi preizkusov razvili osnovno surovino (polnilno maso) za injekcijsko brizganje izdelkov kompliciranih oblik iz prahu zlitine Ti-6Al-4V in ustreznega veziva (plastifikatorja). V tem primeru je bil kot izdelek za preizkuse izbran vijak za kortikalno kost. Določili so kritične in optimalne vsebnosti posameznih komponent polnilne mase oziroma razmerje med volumskim deležem prahu in primernega polimernega veziva. Kritični volumski delež kovinskega prahu je bil $62 \%$, medtem ko je bil optimalni delež $62 \%$. Reološke lastnosti polnilne mase so določili s kapilarnim reometrom, termične lastnosti pa s termo-gravimetrično analizo (TGA). Določili so reološko obnašanje in termične lastnosti mešanic plastifikatorjev: parafin/polietilen/stearinska kislina (PW/PE/SA) in polietilenglikol/polipropilen/stearinska kislina (PEG8000/PP/SA) različnih sestav. S programskim paketom Moldflow so simulirali pretok materiala $v$ orodju za injekcijsko brizganje in na osnovi simulacij dimenzionirali (oblikovali) optimalno obliko vijaka in orodja. Dve vrsti polnilnih mas so identificirali kot skeletni vezivi: propilen (PP) in polietilen (PE) in z njima izvršili simulacije. Pomembno je bilo spoznanje, da ima skeletno vezivo odločilno vlogo za lahek pretok polnilne mase v orodju. Preizkusi in simulacije so pokazali, da je polnilna masa na vodni osnovi primeren vezivni sistem za injekcijsko brizganje vijakov kortikalne kosti.

Ključne besede: osnovna surovina, reologija, injekcijsko brizganje prahu, Ti-6Al-4V, vijak za kortikalno kost

\section{INTRODUCTION}

Titanium and its alloys have outstanding properties in terms of low density, high specific strength, excellent corrosion resistance, high-temperature resistance and non-magnetic properties. Due to these excellent properties, titanium and its alloys are used in many industrial areas. It is especially preferred in the fields of military, defense, automotive, medical and sports equipment. ${ }^{1-3}$ Regardless of these excellent features, its production is limited due to poor process ability and high production costs. Powder production technology provides a good

*Corresponding author e-mail:

levent.urtekin@ahievran.edu.tr solution for eliminating this production problem of titanium and its alloys. However, it is difficult to produce three-dimensional (complex-shaped) parts using the conventional $\mathrm{P} / \mathrm{M}$ method. Less complex-shaped parts are produced using the conventional $\mathrm{P} / \mathrm{M}^{2-3}$ Another attractive method is the powder-injection-molding (PIM) method. The method that can produce clear parts, using microproduction technology is formed by combining plastic injection and powder metallurgy. The production of titanium and its alloys with PIM results in complex shapes, uniform microstructures and high performance. ${ }^{4-5}$ The PIM production consists of four stages. The four-step process includes the stages of mixing, injection molding, debinding and sintering. The mixing step is 
carried out by mixing some of the organic binders identified as binders at low temperatures. The new mix, obtained by mixing powders and binders, is called feedstock. This feedstock fills the mold cavity during molding. We denote the debinding stage as the removal of the binders. It includes two stages: solvent debinding and thermal debinding. In the final step, debinded parts are sintered. Sintering ensures that the samples become fully dense. Feedstock features are very important in the PIM process. The feedstock defines the final properties in the final part. Rheological and thermal properties of a feedstock are two important criteria for powder injection molding and debinding. ${ }^{6-10}$

Ti-alloys were used as an alternative to stainless steel. This is because of the high corrosion resistance and biocompatibility of Ti-alloys. The mechanical properties of Ti alloys are close to those of the bone. Therefore, it has a wide range of uses. ${ }^{11-13}$ If the machining and cutting tool is not suitable, the implant screw is at risk and the optimum performance cannot be achieved. The difficulties of machining Ti-alloy and achieving a series production are overcome with metal-injection molding.

This method is useful in the production of complexgeometry parts that do not require secondary processing, and small parts. ${ }^{14-15}$ The injection-molding step consists of different stages such as heating and melting the raw material, injecting the molten raw material into the mold cavity, bringing the molten raw material into the desired shape, packaging, chilling/solidification and emptying the molded product. ${ }^{16}$ Some defects may occur during the molding of the feedstock. These defects are related to the injection pressure of the feedstock, the pressing pressure and the temperature application. ${ }^{17}$ Some commercial software packages, such as Moldflow, Poly-Flow, Solidworks Flow Simulation and Moldex3D, can be purchased and used to avoid these defects. The Moldflow software is used to estimate the injection parameters of the feedstock during injection molding.

In this study, the MIM method was chosen because of the difficulties in achieving a mass production of both Ti-implant manufacturing and $\mathrm{Ti}$ machining. In this context, experimental and simulation studies were carried out for Ti-alloys to determine the appropriate binders. The feedstock was optimized by mixing titanium alloys and binders. The critical powder-loading rate was determined using a capillary rheometer. The rheological and thermal properties of the feedstocks obtained during the mixing process were investigated. In addition, an implant-screw design was used to examine the flow characteristics for a four-hole mold. For the two different binding systems, the rheology data was supported by simulating an in-mold usage of the PP and PE binders as the basis numerals in the square bracket.

\section{EXPERIMENTAL PART}

\subsection{Materials}

In the study, a spherical Ti-6Al-4V alloy powder was used as the main material. Its density was $4.47 \mathrm{~g} / \mathrm{cm}^{3}$ and the average powder size was 13.4 microns. In Figure 1, a powder-size analysis is shown.

In powder-injection molding, typically, powders smaller than 10 microns in size are used for ceramics, and spherical powders smaller than 20 microns in size are used for metals. ${ }^{1,3,4,9}$ The chemical composition of Ti-6Al-4V is given in Table 1.

Table 1: EDX analysis

\begin{tabular}{|c|c|c|}
\hline Element & $w / \%$ & $\%$ atomic \\
\hline $\mathrm{Al}$ & 5.67 & 9.67 \\
\hline $\mathrm{Ti}$ & 89.61 & 86.07 \\
\hline $\mathrm{V}$ & 4.72 & 4.26 \\
\hline
\end{tabular}

Its powder morphology, determined with scanning electron microscopy, is given in Figure 2.

The binders consist of water-based polyethylene glycol (PEG8000, the main binder), paraffin wax (PW, the main binder), polypropylene (PP, a skeleton binder), polyethylene (PE, a skeleton binder) and stearic acid

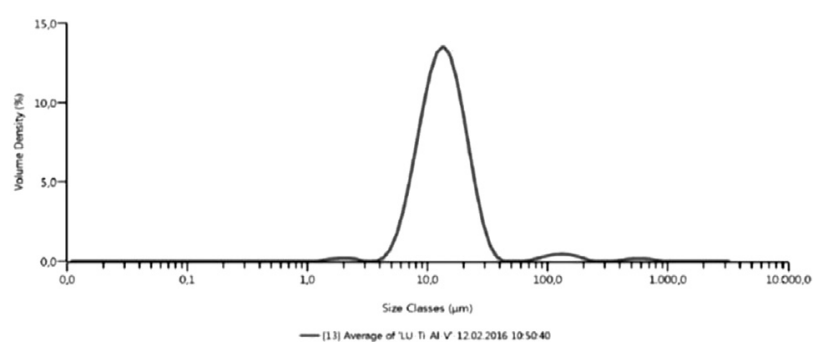

Figure 1: Powder-size analysis

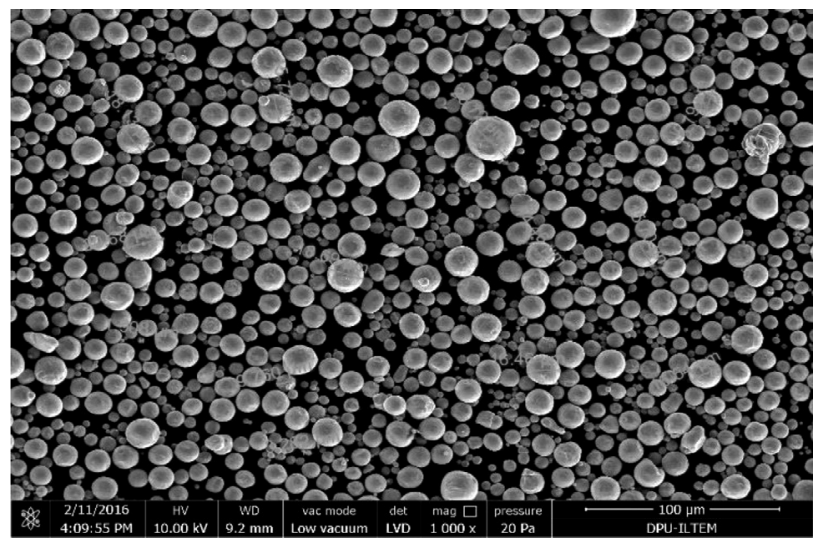

Figure 2: Scanning-electron-microscopy analysis

Table 2: Physical properties of the binders

\begin{tabular}{|c|c|c|c|c|c|}
\hline Property & PW & PEG8000 & PP & PE & SA \\
\hline Density $\left(\mathrm{g} / \mathrm{cm}^{3}\right)$ & 0.92 & 1.204 & 0.85 & 0.91 & 0.94 \\
\hline $\begin{array}{c}\text { Melting } \\
\text { temperature }\left({ }^{\circ} \mathrm{C}\right)\end{array}$ & 51 & 62 & 189 & 170 & $68-70$ \\
\hline
\end{tabular}


(SA, a lubricant). Table 2 gives the physical properties of the binder systems.

\subsection{Method}

The authors carried out the study for two purposes. The first was to provide for a serial production of the implant. The other was to determine whether the MIM method was appropriate. The difference between the preferred binder combinations of $\mathrm{PW} / \mathrm{PE} / \mathrm{SA}$ and PEG8000/PP/SA with respect to a cortical-bone screw implant was investigated in the literature.

Solid loading has a critical effect on a feedstock. Critical solid loading is the most efficient form of the powder-binder ratio. Binders form a thin film layer on a powder, providing for its flow during injection at low temperatures. Therefore, obtaining an optimum powderbinder mixture is a sensitive process for PIM because the flowing material has a high viscosity when the amount of the powder is high, and it exhibits excessively high fluid characteristics when the amount of the powder is low. ${ }^{1,3}$

In this study, the critical powder loading was determined using a capillary rheometer. First, the binders were mixed with each other, and then they were mixed with the Ti-6Al-4V alloy powder at $180{ }^{\circ} \mathrm{C}$ to obtain new granules. The operation was carried out under a vacuum for the obtained granules to be homogeneous and protected from the air. The critical solid loading was determined by passing the granules at different mixing ratios through the capillary. The optimum solid loading was the value below the $2 \%$ critical loading by volume. Another important point here is that the stress density of the powder gives a preliminary idea about the optimum powder loading.

The most important task of the mixing method is to homogenize the powder-binder mixture. It was mixed with a twin-screw extruder at a temperature of $180{ }^{\circ} \mathrm{C}$ at $30 \mathrm{~min}^{-1}$ to pelletize. An indication of the homogeneity of the feedstock is a decrease in the viscosity as the shear rate increases. The rheological behavior of the feedstock affects the injection moldability in a broad sense. The
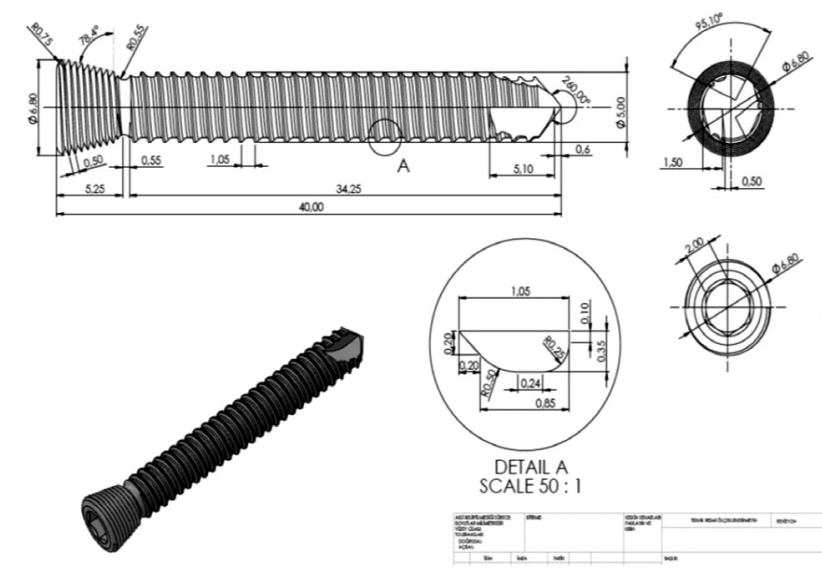

Figure 3: Cortical-bone screw-implant design feedstock viscosity is effective during the filling of the mold cavity. At a low viscosity, jetting occurs in the mold, whereas at a high viscosity, mold filling does not occur. Therefore, the powder-binder ratio and viscosity of a feedstock that is developed are of vital importance. The capillary rheometer was used for determining the feedstock viscosity and shear rate, and they were calculated at temperatures of $180-220^{\circ} \mathrm{C}$ for the two different binder systems.

The debinding behavior is determined with the binding properties, and this step is done as thermal debinding and solvent debinding. Depending on the binder property used, water-soluble or any solution-soluble binders can be used. In this study, the most critical point was the debinding of the main binder using solvent debinding. It is generally recommended that a skeletal binder should be debinded with thermal debinding. Thermal debinding was performed by obtaining the information about the thermal behavior of the feedstock using a TGA analysis. In the TGA analysis, the behavior of the feedstock was determined by heating it by $5{ }^{\circ} \mathrm{C} / \mathrm{min}$, to $600{ }^{\circ} \mathrm{C}$ and in an argon atmosphere.

Cortical-bone screw implants are now produced by machining. In the study proposed, we aimed to produce them with the MIM method. The most important factor here is the difficulty of a serial production and Ti machining. A standard screw that is easily applied to every person is preferred in the study. A cortical-bone screw, which is an orthopedic implant, is designed with reverse engineering and Figure 3 shows its design. The mold design was done according to the screw geometry and a Moldflow simulation analysis was performed for the skeletal binders that are essential for the feedstock. From many studies reported in the literature, it is known that a feedstock behaves in accordance with the skeletal binding properties of the feedstock. It was aimed to be supported by PW/PE/SA- PEG8000/PP/SA rheology data prior to molding it with a simulation analysis.

\section{RESULTS}

\subsection{Determination of the optimal solid loading}

Prior to the capillary-rheometer experiments, the binders were mixed with each other in a dry medium for $45 \mathrm{~min}$ at a ratio of 65:30:5. The mixture was then mixed for $45 \mathrm{~min}$ with $\mathrm{Ti}-6 \mathrm{Al}-4 \mathrm{~V}$ using a three-dimensional stirrer and passed through a twin-screw extruder $\left(180^{\circ} \mathrm{C}\right.$, $30 \mathrm{~min}^{-1}$ ) to obtain homogeneous granules. The obtained homogenous granules were passed through a capillary rheometer to determine the optimum solid loading. The variation in the viscosity values by time at different solid loads taken from the capillary rheometer are given in Figures $\mathbf{4 a}$ and $\mathbf{4 b}$.

The solid-loading rate for the PEG8000/PP/SA feedstock was between $50-62 \%$. No flow occurred at the $62-\%$ solid loading. This shows that the critical loading for this binder was determined to be $62 \%$. The optimum 
L. URTEKIN et al.: FABRICATION AND SIMULATION OF FEEDSTOCK FOR TITANIUM-POWDER ...
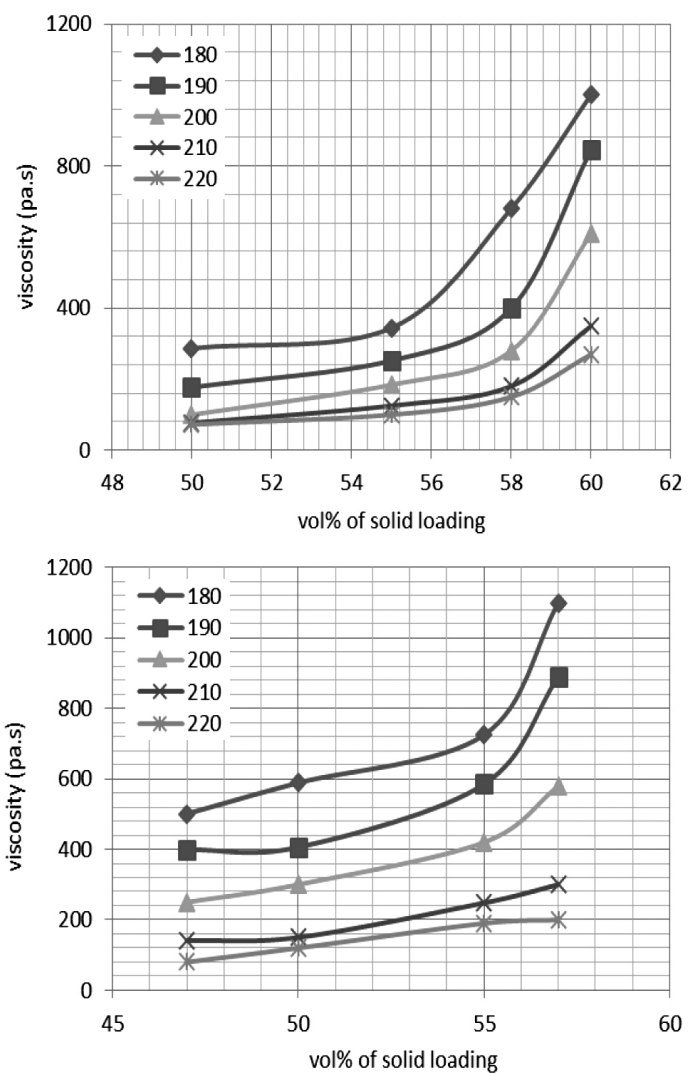

Figure 4: Capillary-rheometer results for: a) PEG8000/PP/SA, b) PW/PE/SA feedstock solid loadings
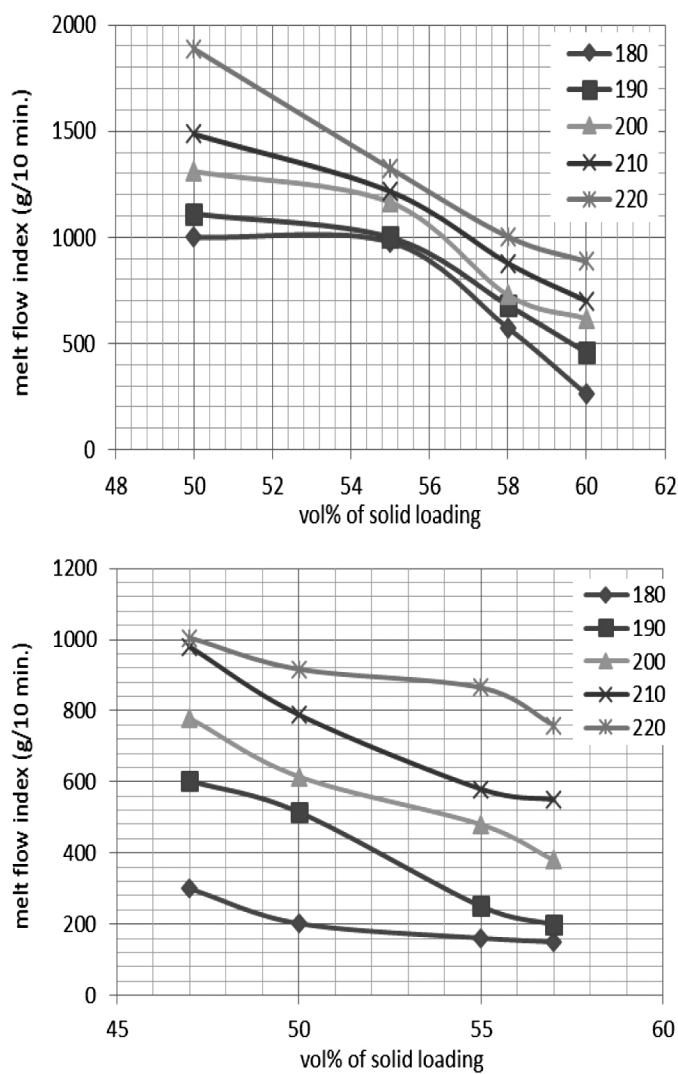

Figure 5: Melt-flow index versus vol.\% solid loading for: a) PEG8000/PP/SA, b) PW/PE/SA feedstocks loading for the same binder was $60 \%$ by volume. In Figure $4 \mathbf{b}$, the solid-loading rate for the PW/PE/SA feedstock was between 47-59\%. No flow occurred at the $59-\%$ solid loading. This shows that the critical loading for this binder was determined to be $59 \%$. In other words, the rate at which the flow does not occur is the rate at which the critical load occurs. The optimum loading for the same binder was $57 \%$ by volume.

The melt-flow index indicates the amount of the feedstock flowing through the extruder in $10 \mathrm{~min}$. In Figures $\mathbf{5} \mathbf{a}$ and $\mathbf{5 b}$, the melt-flow index and the change in the solid loading are given. Powder-binder separations and inhomogeneous mixtures were observed at solidloading values of $50 \%$ and below by volume. The PEG8000/PP/SA feedstock appears to be superior to the $\mathrm{PW} / \mathrm{PP} / \mathrm{SA}$ feedstock in terms of melt-flow index values.

\subsection{Rheological behavior of the Ti-6Al-4V feedstock}

The viscosity and shear rate were determined using the capillary rheometer. The viscosity-temperature change and viscosity-shear-rate changes for different feedstocks at $180-220{ }^{\circ} \mathrm{C}$ are given in Figures 6 and 7. At these temperatures, it was seen that as the viscosity increased, the shear rate decreased and the flow type became pseudo-plastic. In the literature; ${ }^{1,3,4}$ it is expected that a successful feedstock has a viscosity lower than $1000 \mathrm{~Pa} . \mathrm{s}$ and a shear rate of $100-10000 \mathrm{~s}^{-1}$.
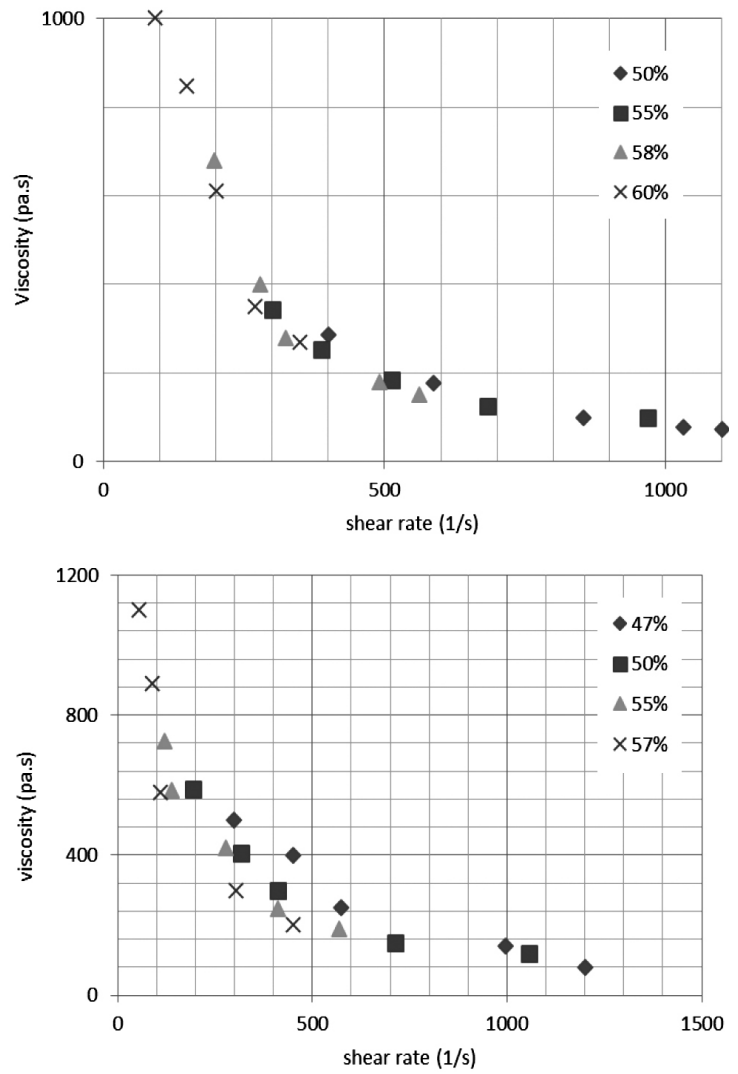

Figure 6: Viscosity versus shear rate for: a) PEG8000/PP/SA, b) PW/PE/SA feedstocks 

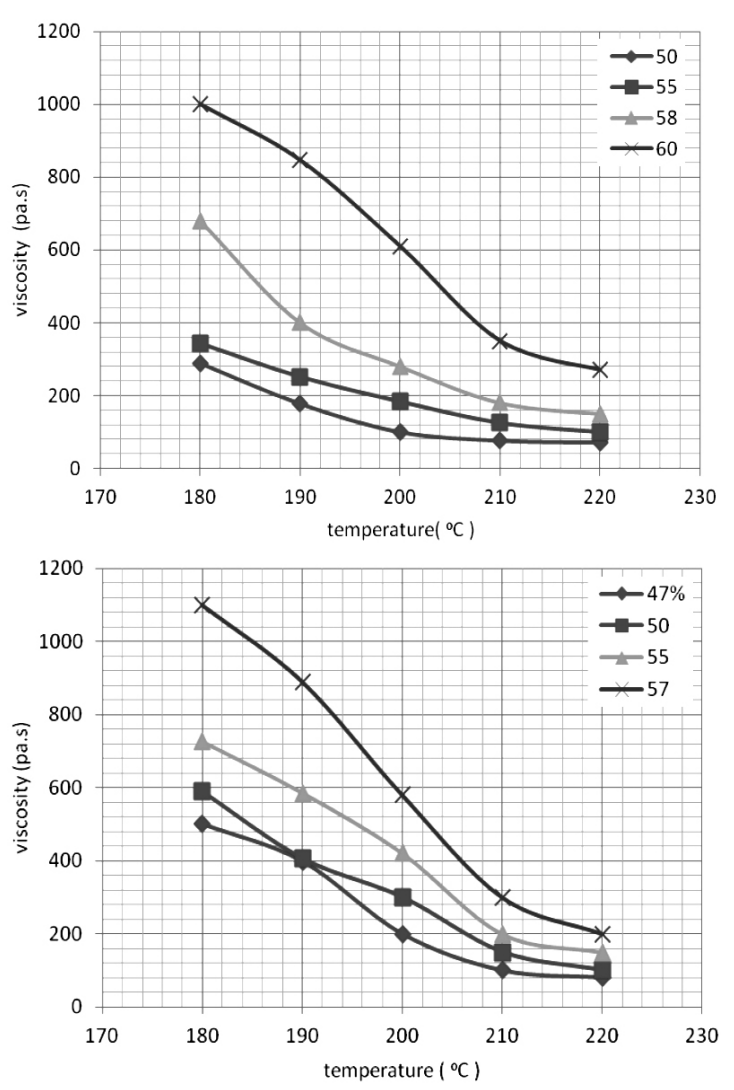

Figure 7: Viscosity versus temperature for: a) PEG8000/PP/SA and b) $\mathrm{PW} / \mathrm{PE} / \mathrm{SA}$ feedstocks

As shown in Figure 6a, it was calculated that the viscosity of the PEG8000/PP/SA feedstock varied from $1001 \mathrm{~Pa} \mathrm{~s}$ to $72 \mathrm{~Pa} \mathrm{~s}$ and the shear rate from $92 \mathrm{~s}^{-1}$ to $1100 \mathrm{~s}^{-1}$. As shown in Figure $\mathbf{6 b}$, it was calculated that the viscosity of the PW/PE/SA feedstock varied from $1100 \mathrm{~Pa} \mathrm{~s}$ to $80 \mathrm{~Pa} \mathrm{~s}$ and the shear rate from $55 \mathrm{~s}^{-1}$ to $1200 \mathrm{~s}^{-1}$. The viscosity-temperature change for the feedstocks at $180-220^{\circ} \mathrm{C}$ is shown in Figure 7.

\subsection{Thermal analyses of the feedstocks}

The thermal behaviors of the feedstocks were obtained using a TGA analysis. The TGA analysis provides an important optimization for thermal debinding. In Figure 8, the weight loss of the Ti-6Al-4V feedstocks was determined at a certain heating rate. Figure 8a shows the thermal behavior of the PEG8000/PP/SA feedstock and Figure $\mathbf{8 b}$ shows the thermal behavior of the PW/PE/SA feedstock. The binders for both feedstocks were completely debinded at $550{ }^{\circ} \mathrm{C}$. However, this process was carried out under a special protective atmosphere.

The shear stress/shear rate relation is defined as follows:

$$
\tau-\tau_{y}=k(\gamma)^{m}
$$

where $\tau$ denotes the shear stress, $\mathrm{k}$ denotes the constant, $\gamma$ denotes the shear rate, and $m$ denotes the flow-beha-

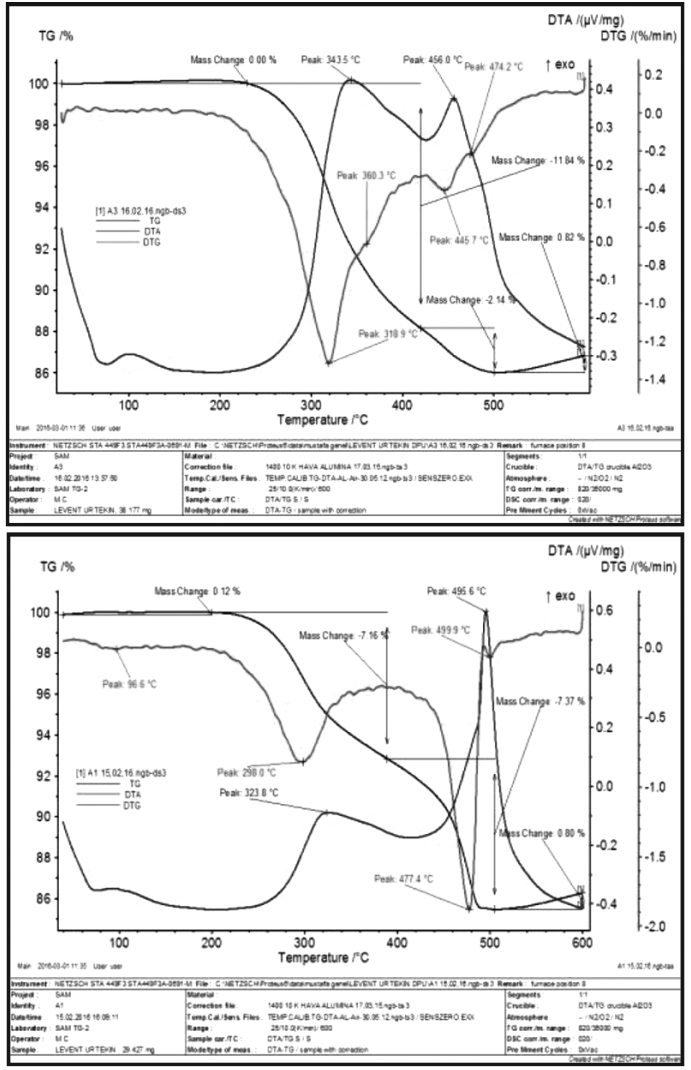

Figure 8: TGA analysis of feedstocks

vior index. ${ }^{3,10}$ For all the feedstocks, the flow-behavior index was less than 1 , ranging from 0.507 to 0.601 .

In the literature, the flow-behavior indices of the feedstocks prepared with HDPE alumina, Ti alloy and PEG alumina are in ranges of $0.522-0.529,0.50-0.56$ and $0.41-0.66$, respectively, and are in agreement with the experimental data obtained within the scope of the study. In this context, all of the feedstocks tested were pseudo-plastic and suitable for injection molding in terms of flow-behavior indices and were compatible with

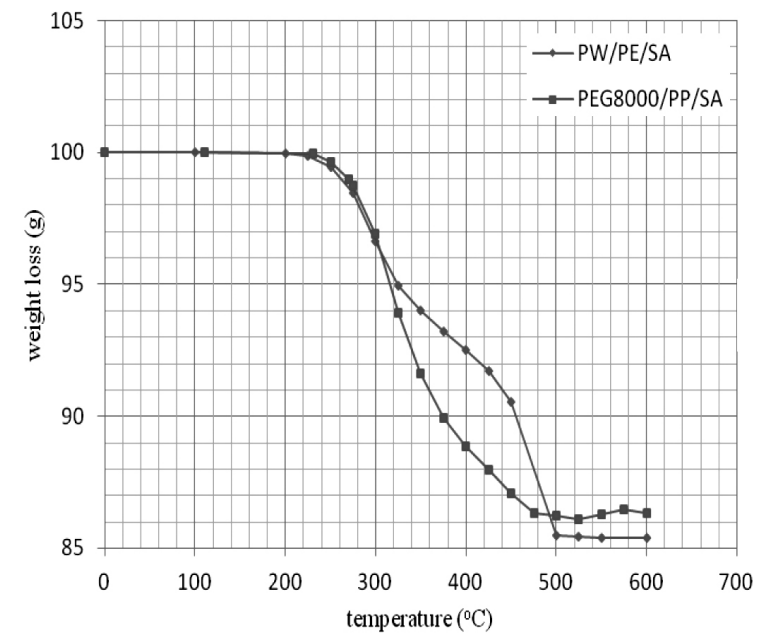

Figure 9: Weight loss versus temperature of the PEG8000/PP/SA and PW/PE/SA feedstocks 


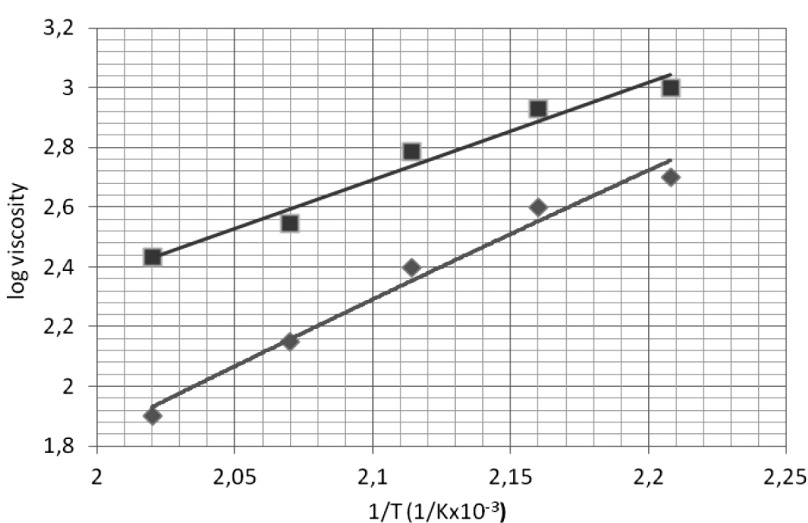

Figure 10: Activation energy for feedstocks

the data from the literature. ${ }^{10}$ In Figure 9, the debinding of the binders from the feedstocks is given based on the temperature. At a temperature of $550{ }^{\circ} \mathrm{C}$, the binders were debinded and the pre-sintering was completed.

Another factor for the feedstock rheology is the activation energy. It is important that the feedstock in injection molding has a low viscosity and low activation energy. For the feedstocks, the following equation is used
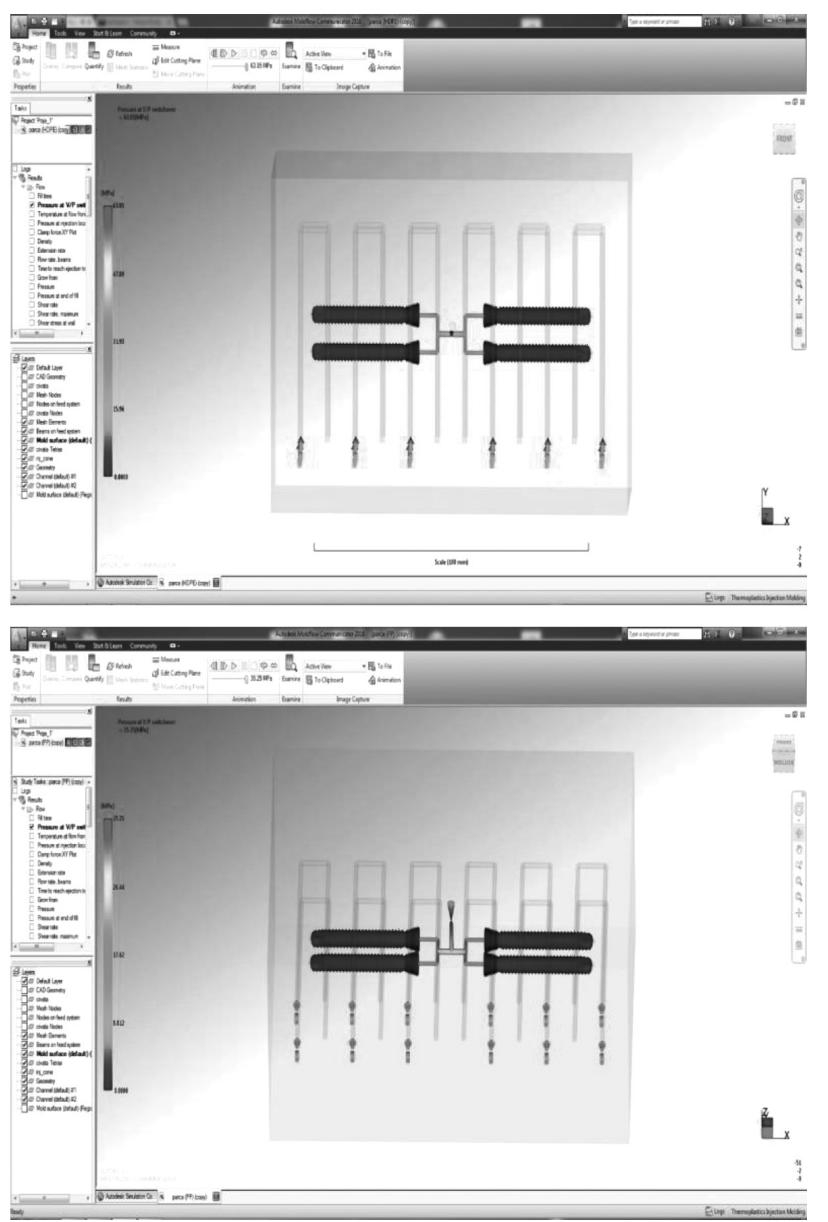

Figure 11: Injection-pressure analysis for $\mathrm{PE}$ and $\mathrm{PP}$
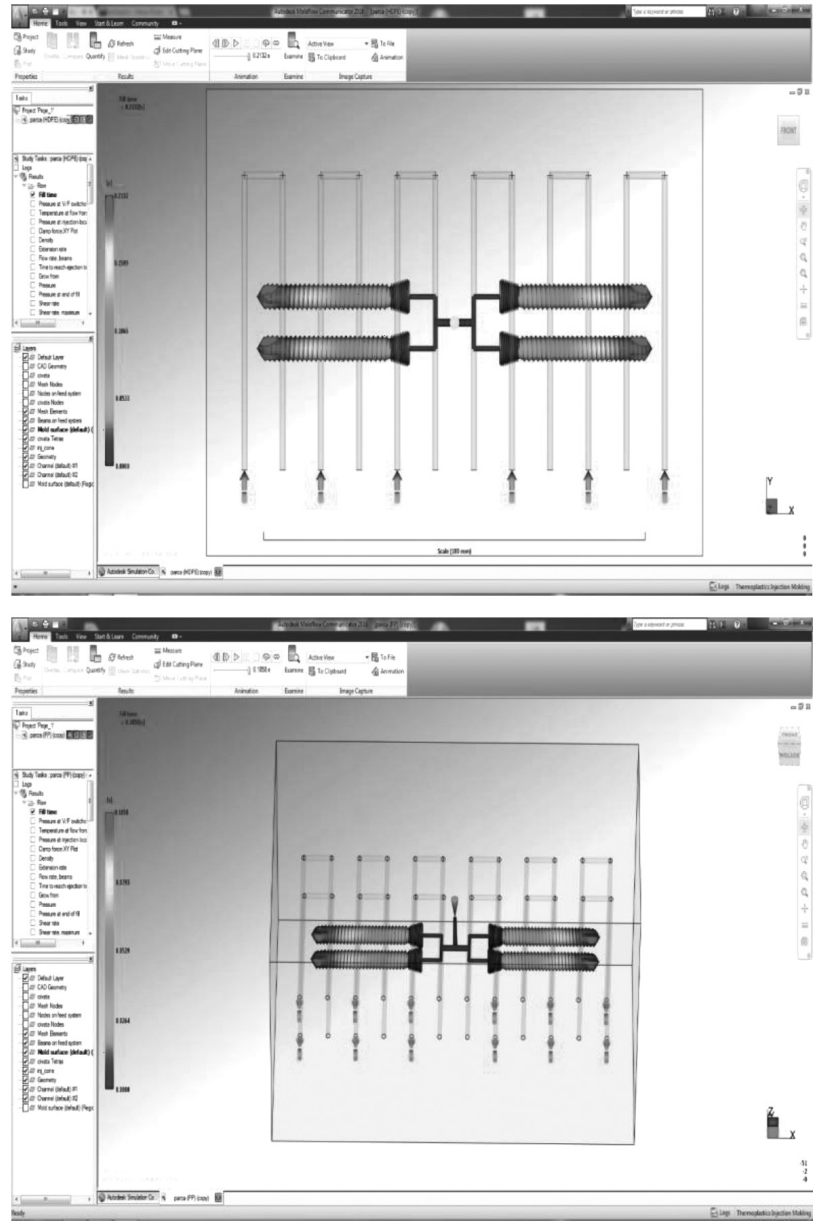

Figure 12: Filling-time analysis for PE and PP

$$
\log \eta=E a / R(1 / T)
$$

to find the activation energy from the logarithmic viscosity and $1 / T$ variations.

Here, $E a$ is the flow activation energy, $R$ is the ideal gas constant $(R=8.31 \mathrm{~J} / \mathrm{molK})$ and $\eta$ is the viscosity. In injection molding, it is desirable to have low activation-energy situations. A low flow activation energy means that the energy required for the flow is low, i.e., the viscosity is low. ${ }^{3}$ When Figure $\mathbf{1 0}$ is examined, it is seen that the PEG8000/PP/SA feedstock is better in terms of activation energy.

\subsection{Cortical-bone screw-implant design and simula- tion}

The bone screw still currently in use was designed with reverse engineering due to the difficulties of the processing of the Ti-6Al-4V cortical screw bone and its serial use, and a four-hole mold was manufactured. The parameters related to molding were given in another study. ${ }^{4}$ Mold-filling simulations were performed using the Autodesk Moldflow 2014 software. The rheological and thermal properties of the feedstock were measured and used for mold-filling simulation studies of the corti- 
cal-bone screw geometry. Simulation studies determined appropriate processing conditions for injection molding cortical-bone screws. The results obtained with the simulation studies were investigated based on the feedstock characteristics determined by the mold-filling behavior and rheology. Figure 11 shows the injection pressure (PE and PP) and Figure 12 shows the filling time (PE and PP). The simulation study was carried out using two different feedstocks. The first one included PE (PW/PE/SA) and the other included PP (PEG8000/ $\mathrm{PP} / \mathrm{SA})$. Previous work indicated that the feedstock has skeletal binding properties. In this context, using a simulation study, the injection pressure for PE was $62.18 \mathrm{MPa}$, the mold filling time was $0.21 \mathrm{~s}$, the flow rate was $24.21 \mathrm{~cm}^{3} \mathrm{~s}^{-1}$ and the injection temperature was $238{ }^{\circ} \mathrm{C}$. In the analyses made for PP, the injection pressure was $35.25 \mathrm{MPa}$, the mold filling time was $0.10 \mathrm{~s}$, the flow rate was $12.11 \mathrm{~cm}^{3} \mathrm{~s}^{-1}$ and the injection temperature was $232{ }^{\circ} \mathrm{C}$. As in the study of rheology, it is seen that the PP skeletal-binding feedstock is more suitable for the simulation study.

\section{CONCLUSIONS}

In conclusion, the rheological and thermal properties of Ti-6Al-4V feedstocks were optimized in this study. The debinding temperature and environment of the binding systems of the prepared feedstocks were determined. The wax-polymer system and the polyethylene glycolpolymer system were compared. Especially for the molding of complex-shaped geometries, it was determined that it is appropriate to mold the powder-binder ratio at volumetric mixing ratios that are lower at a certain level than the determined ratio. The PEG8000/ PP/SA feedstock (with a volume of $60 \%$ ) was found to be superior in terms of rheological and thermal properties to the PW/PE/SA feedstock (with a volume of $57 \%$ ). Higher solid loadings can be tried for PEG-based feedstocks using finer powders. The Ti-6Al-4V cortical-bone screw molding with a volumetric $60-\%$ PEG8000/PP/SA feedstock was successfully accomplished. As a result of the Moldflow simulation, experiments using the PP skeleton binder for the PEG8000/ PP/SA feedstock were found to be more suitable for the injection pressure, flow rate and filling-time parameters.

\section{REFERENCES}

${ }^{1}$ R. M. German, Progress in titanium metal powder injection molding, Mater., 6 (2013), 3641-3662, doi:10.3390/ma6083641
${ }^{2}$ S. J. Park, Y. Wu, D. F. Heavy, X. Zou, G. Gai, R. M. German, Rheological and thermal debinding behavior in titanium injection molding, Metall. Mater. Trans. A, 40A (2009), 215-222, doi:10.1007/s11661-008-9690-3

${ }^{3}$ R. M. German, A. Bose, Injection Molding of Metals and Ceramics, Metal Powder Industries Federation, New York 1997

${ }^{4}$ L. Urtekin, A. Taşkın, Ti-6Al-4V alloy cortical bone screw production by powder injection molding method, Mater. Exp., 7 (2017) 4 , 245-252, doi:10.1166/mex.2017.1378

${ }^{5}$ S. Guo, X. Qu, X. He, T. Zhou, B. J. Duan, Powder Injection Molding of Ti-6Al-4V alloy, Mater. Process. Technol., 173 (2006), 310-314, doi:10.1016/j.jmatprotec.2005.12.001

${ }^{6}$ O. M. Ferri, T. Ebel, R. Bormann, High cycle fatigue behavior of Ti-6Al-4V fabricated by metal injection molding technology, Mater. Sci. Eng. A, 504 (2009), 107-113, doi:10.1016/j.msea.2008.10.039

${ }^{7}$ A. Kei, K. Yasunari, I. Hiromichi, T. Masaharu, Injection Molding of Titanium Powders, Adv. Powder Metall., 3 (1989), 121-126

${ }^{8}$ D. Lin, S. T. Chung, Y. S. Kwon, S. J. Park, Preparation of Ti-6Al$4 \mathrm{~V}$ feedstock for titanium powder injection molding, J. Mech. Sci. and Tech., 30 (2016) 4, 1856-1864, doi:10.1007/s12206-016-0343-y

${ }^{9}$ L. Urtekin, I. Uslan, B. Tuc, Investigation of properties of powder injection-molded steatites, J. Mat. Eng. and Perf., 3 (2012), 358-365, doi:10.1007/s11665-011-9901-8

${ }^{10}$ L. Urtekin, I. Uslan, B. Tuc, Investigation of Effect of Feedstock Rheologies for Injection Molding of Steatite, J. Fac. Eng. Arch. Gazi Uni., 27 (2012) 2, 333-341

${ }^{11}$ M. J. Yaszemski, D. J. Trantolo, K. U. Lewndrowski, V. Hasirci, D. E. Altobelli, D. L. Wise, Biomaterials in orthopedics, Marcel Dekker, New York 2004

${ }^{12}$ L. Reclaru, R. Lerf, P. Y. Eschler, J. M. Meyer, Corrosion behavior of a welded stainless-steel orthopedic implant, Biomat., 22 (2001), 269-279, doi:10.1016/S0142-9612(00)00185-X

${ }^{13}$ R. W. Wei Hsu, C. C. Yang, C. A. Huang, Y. S. Chen, Electro-chemical corrosion properties of Ti-6Al-4V implant alloy in biological environment, Mater. Sci. and Eng. A, 380 (2004), 100-109, doi:10.1016/j.msea.2004.03.069

${ }^{14}$ P. F. Santos, M. Niinomi, H. Liu, K. Cho, M. Nakai, Y. Itloh, Fabrication of low-cost beta-type Ti-Mn alloys for biomedical applications by metal injection molding process and their mechanical properties, J. Mech. Behav. Biomed. Mater., 59 (2016), 497-507, doi:10.1016/j.jmbbm.2016.02.035

${ }^{15}$ M. F. F. A. Hamidi, W. S. Harun, M. Samykano, S. A. C. Ghani, Z. Ghazalli, F. Ahmad, A. B. Sulonge, A review of biocompatible metal injection molding process parameters for biomedical applications, Mater. Sci. Eng. C, 78 (2017), 1263-1276, doi:10.1016/j.msec.2017. 05.016

${ }^{16}$ D. M. Nuruzzaman, N. Kusaseh, S. Basri, A. N. Oumer, Z. Hamedon, Modeling and flow analysis of pure nylon polymer for injection molding process, Conf. Ser.: Mater. Sci. Eng., 114 (2016), doi:10.1088/1757-899X/114/1/012043

${ }^{17}$ X. Wanga, G. Zhao, G. Wanga, Research on the reduction of sink mark and warpage of the molded part in rapid heat cycle molding process, Mater. and Des., 47 (2013), 779-792, doi:10.1016/j.matdes. 2012.12.047 